\title{
NOTES ON THE TYPE SPECIMENS OF THREE SPECIES OF JAPANESE MOLLUSCS DESCRIBED BY F. JOUSSEAUME
}

\section{$\operatorname{AUTHOR}(S)$ :}

Habe, Tadashige

\section{CITATION:}

Habe, Tadashige. NOTES ON THE TYPE SPECIMENS OF THREE SPECIES OF JAPANESE MOLLUSCS DESCRIBED BY F. JOUSSEAUME. PUBLICATIONS OF THE SETO MARINE BIOLOGICAL LABORATORY 1953, 3(2): 169-172

\section{ISSUE DATE:}

1953-12-20

URL:

http://hdl.handle.net/2433/174471

RIGHT: 


\title{
NOTES ON THE TYPE SPECIMENS OF THREE SPECIES OF JAPANESE MOLLUSCS DESCRIBED BY F. JOUSSEAUME*
}

\author{
TADASHIGE HABE \\ Zoological Institute and Seto Marine Biological Laboratory, \\ Kyoto University \\ With Plate IX
}

Though three Japanese species had been described in the French journal "Le Naturaliste" by F. JousSEAume in 1894 and 1899, their type specimens were not figured until to-day. Fortunately enough, Dr. Max DESJARDIN sent me the photographs of Guildfordia yoka, Malvufundus irregularis and Pinna epica, preserved in the Muséum National d'Histoire Naturelle de Paris, together with copies of their original descriptions. They are here published by the kind permission of the Director of the above Museum and Dr. M. DesJardin. As the above-mentioned journal is far from accessible in Japan, the redescriptions and illustrations of these original specimens may be useful to workers on the Mollusca.

Thanks are due to the Director of the Muséum National d'Histoire Naturelle de Paris and Dr. M. DesJARDIN for their kindest cooperation. Also I am grateful to Dr. Tokubei Kuroda and Dr. Iwao Taki for their warm suggestions.

\section{Malleus (Parimalleus) irregularis (JOUSSEAUME)}

(P1. IX, Figs. 3, 4)

1894 Malvufundus irregularis JousseAUME, Le Naturaliste, (2) 8 (16), p. 228.

"Testa irregularis, depressa, fere ovalis, antice et postice inaequaliter biolata, corneo-cutea, maculis nigrescentis irregulariter aspersa, concentrice striata, versus apicem lamellis concentrice instructa, cauda curcata, ala longissima fisso a cauda disjuncto.

Dimensions; haut., 30 millimétres; larg., 52 millimétres; épaiss., 7 millimétres.

Hab. : Japon."

The type specimen of this species is abnormal in shape, for the normal specimens from various localities from Japan are generally very large in height and very narrow

* Contributions from the Seto Marine Biological Laboratory, No. 215.

Publ. Seto Mar. Biol. Lab., III (2), 1953. (Article 16) 
in breadth, lacking the winged processes at the extremities of hinge line. This is very common under stones and in their crevices between tidal marks on the Pacific coast of southern Japan.

\section{Atrina (Servatrina) epica (JoUSSEAUME)}

(P1. IX, Figs. 1, 2)

1894 Pinna epica Jousseaume, Le Naturaliste, (2) 8 (16), p. 229.

1953 Atrina (Servatrina) epica HABE, Illust. Cat. Jap. Shells, 24, p. 194, pl. 25, fig. 8.

"Testa subtrigono-ovalis, subventrosa, apice latissima hians $2 / 3$ longitudinis superante, basi mucronato-acuta, fulvo grisea, inferne violaceo-nigra, transversim undulatoplicata et radiatim irregulariter costata, costis evanidis undulatis inaequaliter exsertis.

Dimensions; long., 156 millimétres; larg., 65 millimétres ; épaiss., 27 millimétres.

Hab. : Japon:"

Compared with my specimens at hand collected off Wakayama and Tosa Bay, Shikoku, the type specimen of this species is very large, but the surface sculpture of this specimen is poorly preserved, probably due to the long stay in the mud. In the perfect specimens, the surface is covered with longitudinally radiated narrow cords on which minute scales are arranged at the points of intersection of the growth lines, giving the surface a reticulated aspect. Atrina tenuis HABE from Tosa Bay resembles this pretty species, but the former is uniformly coloured light yellow and provided with distantly radiate narrow cords on which moderately large scales are set.

\section{Guild fordia yoka JoUSSEAUME}

(Pl. IX, Figs. 5, 6)

1899 Guildfordia yoka JOUSSEAUME, Le Naturaliste, (2) 13 (21), p. 48.

1908 Guildfordia yoca SCHEPMAN, Exped. Siboga, 49a, p. 26.

“Testa depresso-conica, supra purpureo-rufescens, inferius cinereo-alba, callosoumbilicata, callositas margaritacea profunde excavata; anfr. 7 , depressi, convexiusculi, circum sucturam seriebus granulis (7-8) dense ingulati, ad peripheriam radiatim rugosoplicat, ultimus inferne convexus, striis radiatibus, falcatis et spiralibus minutissime decussatus; prope callositatem linea rosea circumcurrente pictus, spinis longissimis, subdistantibus radiatus; sutura impressa spinis obtectantibus interrupta; apertura oblique ovalis; labrum sinuatum margaritaceum.

Dimensions; Diam. maj. 53 millimétres; Min. 45 millimétres; Altitude; 27 millimétres. 
Hab. : Japan."

This is a second species of Guildfordia which was established by GRAY 1850 for Astralium triumphans PHILIPPI. Though this type specimen is very large in size, the characteristic long spines on the periphery are entirely lost at the distal portion. The type specimen, however, agrees completely with the specimens before me which were collected from the deep bottom of Tosa Bay, Shikoku and off Wakayama Pref., Honshu. The locality of this type species was described only as Japan. Moreover, this species has been recorded from the East Indies in the molluscan reports of "Siboga Expeditie" by SCHEPMAN (1908) with some slight discrepancies from the Japanese specimens. This curious species differs from G. triumphans, which is widely distributed in East Indies, China and Japan, and is common off Minabe, Wakayama Pref,, Honshu, by very long spines at the periphery and absence of the beaded spiral cords on the base. 


\section{EXPLANATION OF PLATE IX}

Figs. 1, 2. Atrina (Servatrina) epica (Jousseavme).

Figs. 3, 4. Malleus (Parimalleus) irregularis (Jousseaume).

Figs. 5, 6. Guildfordia yoka Jousseaume. 
Publ. Seto Mar, Biol. Lab., III, 2 (1953) PLATE IX

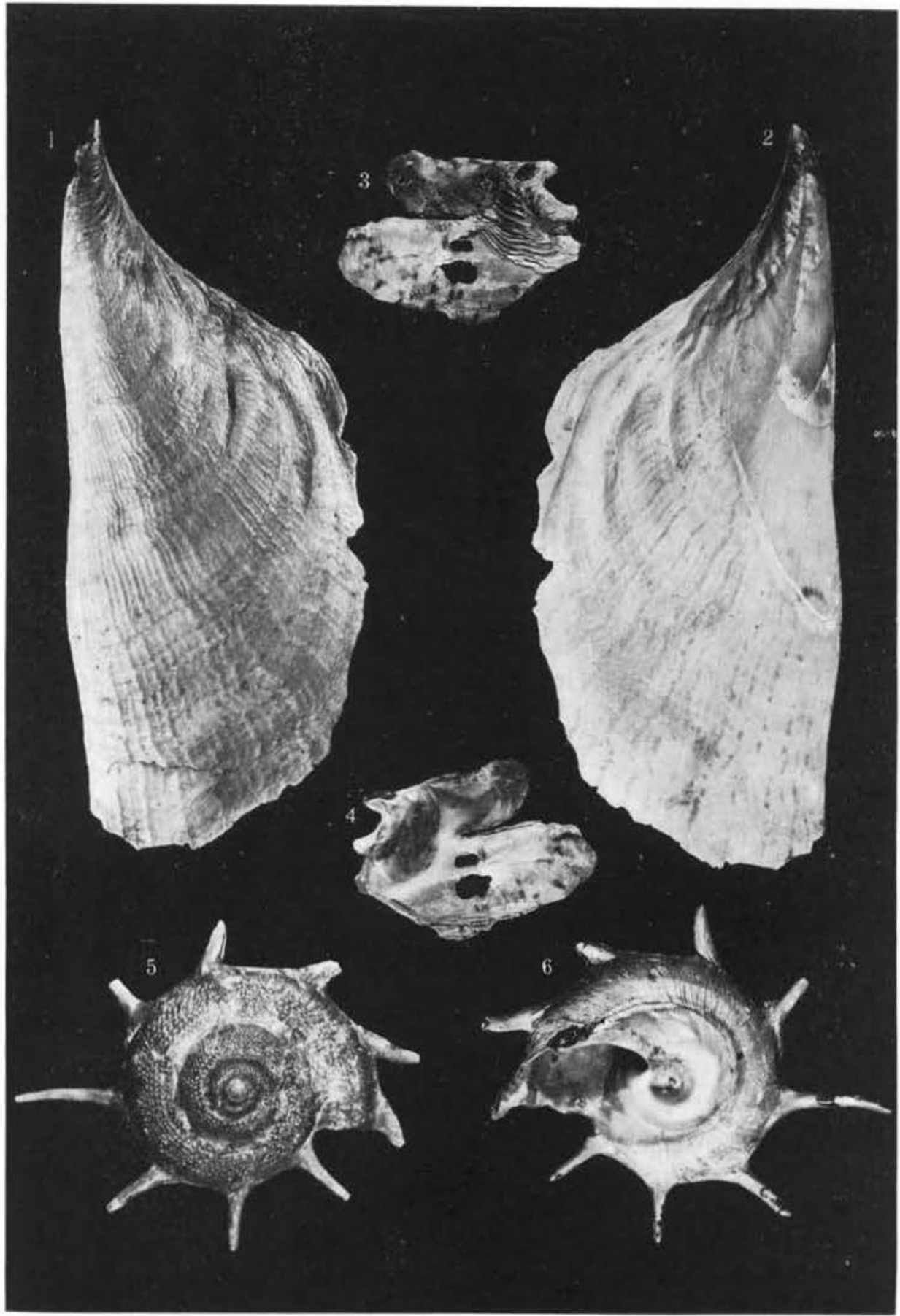

T. Habe: Type Specimens of Molluscs Described by Jousseaume. 